The BDJ News section accepts items that include general news, latest research and diary events that interest our readers. Press releases or articles may be edited, and should include a colour photograph if possible. Please direct your correspondence to the News Editor, Arveen Bajaj at the BDJ, 64 Wimpole Street WIG 8YS or by email to bdj@bda.org

\section{Royal award}

The Royal Society for the Promotion of Health has awarded the inaugural Queen Elizabeth Medal to Dr Lynette Coetzee, who founded the Transnet Phelophepa Health Care Train in South Africa in 1994.

Phelophepa - a hybrid name derived from Sotho and Tswana and meaning 'good clean health' - began operating as a mobile primary healthcare clinic in 1994 and has reached more than 1.1 million people since inception of the programme.

The initial 13-coach train provided healthcare and education to rural communities across South Africa. Now 16 coaches long, the Phelophepa Train contains eye, health and dental clinics with X-ray facilities and provides HIV/AIDS and counselling workshops.

His Royal Highness, Prince Philip, the Duke of Edinburgh, presented the award at The Royal Society for the Promotion of Health Annual Awards Ceremony at Claridge's, London. The society celebrates 100 years of royal patronage this year, and in order to mark this milestone, its patron, Queen Elizabeth, gave permission for the society to introduce a new award, the Queen Elizabeth Medal.

The medal is to be awarded annually to encourage and recognise individuals who make an outstanding contribution to public health within the Commonwealth.

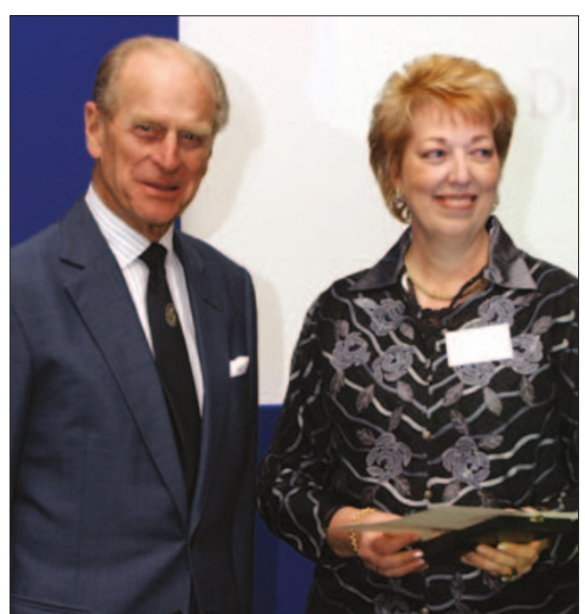

His Royal Highness, Prince Philip presenting the award to Dr Lynette Coetzee

\section{Pilot project launched}

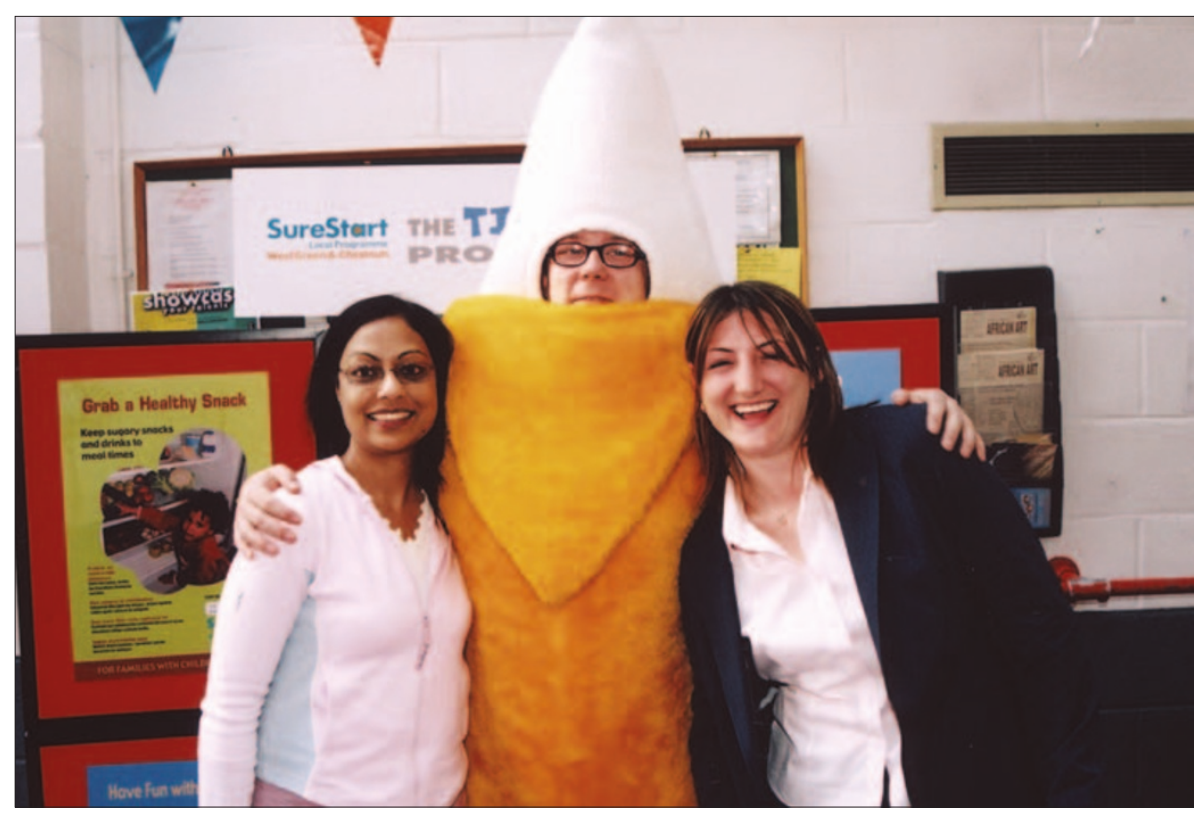

Nine NHS dental practices were recruited to take part in the Tiny Teeth pilot project in Haringey recently. The project, run by West Green and Chestnuts Sure Start, aims to give support to families with 0-4-yearold children to help prevent tooth decay and to help families register with local dentists. Oral health educator Kim Powell, (right) practice manager Mrs Vasu Shah (left) together with 'bananaman' Daniel Kowalski (centre) are pictured at the launch of the scheme, which also offers training to dental nurses and capital to dentists to make their practices more 'child friendly'.

\section{Promoting standards}

The General Dental Council (GDC) and the Joint Board of the UK Voluntary Register for Public Health Specialists (Joint Board) have signed a Memorandum of Understanding.

The Memorandum describes how the two organisations are working together to protect patients and promote high standards in public health practice.

The Memorandum clarifies the respective roles and responsibilities of the GDC and the Joint Board in relation to registering dentally qualified

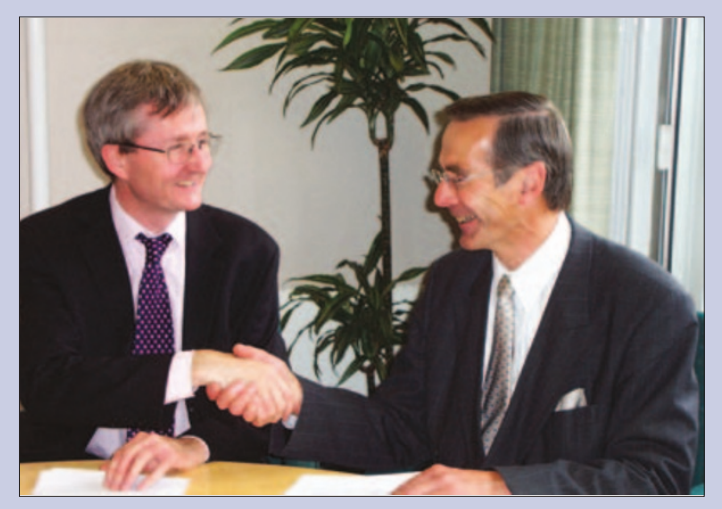

Antony Townsend GDC Chief Executive and Registrar with Jim McEwen, Chair of the Joint Board of the UK Voluntary Register for Public Health Specialists public health specialists. It also outlines the mechanisms that are in place for the exchange of information between the two organisations in the interests of patient protection. The Joint Board is an independent regulatory body that aims to promote public confidence in specialist public health practice in the UK. 


\section{DIARY}

September 2004

British Orthodontic Conference

Date: 19-22.09.04

Venue: Harrogate

Contact: Ann Wright

Tel: +44 (0)207 8372193

Email: ann.wright@bos.org.uk www.bos.org.uk

\section{October 2004}

The University of the West Indies Second

Biennial Conference, Health Sciences,

Research and Education in Focus in the

Caribbean

Date: 11-14.10.04

Venue: Mount Hope Medical Complex,

Trinidad

Contact: Dr Trevor Alleyne

Tel: (868) 6459865 ext 5102, 5020,

4643,4645

Fax: (868) 6459865

Email: trevnmar@tstt.net.tt

The 28th Annual International Conference of the American Society for Dental

Aesthetics

Date: 14-16.10.04

Venue: Fairmont Scottsdale Princess

Resort, Scottsdale, Arizona, USA

Tel: 1-888-988-ASDA

www.asdatoday.com

Leeds Dental School Centenery

Date: 16.10 .04

Venue: Leeds

Contact: Gayle Williams

Tel: 01133436138

Email: g.williams@leeds.ac.uk

\section{Behind the potting shed}

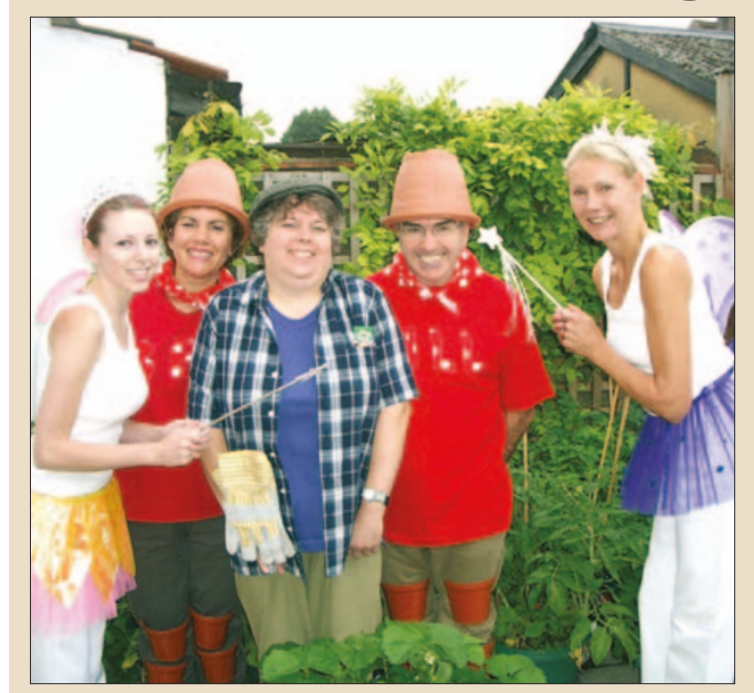

\section{Change of name for independent body}

An independent body launched to promote the interests of the public in the regulation of the healthcare professions such as the GDC will now be known as the Council for Healthcare Regulatory Excellence (CHRE).

The group changed its name from the Council for the Regulation of Healthcare Professionals (CRHP) because it believed it better reflected the role and purpose of the UK-wide organisation and avoided possible confusion with bodies of a similar name.

The new name takes immediate effect and will be part of the Council's corporate identity to be officially launched with the publication of its first annual report to Parliament in the autumn. The Council was established on 1 April 2003 to promote the interests of the public and patients in the
Dr Patrick Donohoe and Dr Amalia Liguori along with their staff had a surprise for patients attending the Dartford Road Dental Centre recently. The practice took part in the annual 'Dress up for Dentaid Day' to help raise funds for dentistry and oral health programmes in the developing world. Tomato plants were sold to patients to help raise funds and dental care was provided by the flowerpot men, with the help of the garden fairies and the gardener.

regulation of the healthcare professions, promote best practice in the regulation of the healthcare professions, develop principles for good professionally-led regulation and to promote co-operation between regulatory bodies and other organisations.

The CHRE is an overarching, independent body which oversees the regulatory work of nine organisations which includes the General Dental Council, the General Medical Council, the General Optical Council and the General Osteopathic Council.

Referrals of cases to court under Section 29 of the National Health Service Reform and Health Care Professions Act 2002 will for the time being be brought under the name of CRHP because this is currently the statutory name of the organisation. 


\section{Practices recognised}

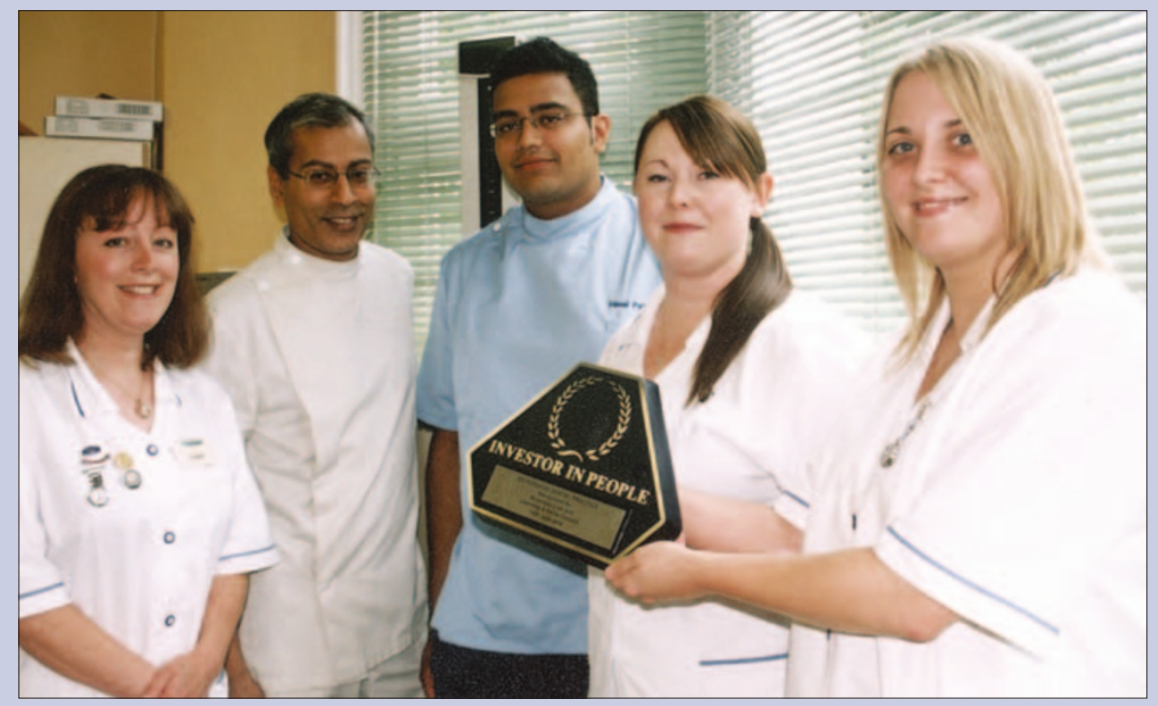

The Dental Practice in Thornton Heath was recently recognised as an Investor in People. To gain the award the practice took part in a six month scheme with six other dental practices. From left to right: dental nurse Angela Lewis, principal Dr Siddharth Persaud, VDP Dr Hinal Patel, and dental nurses Lea Williams and Rebecca Jury.

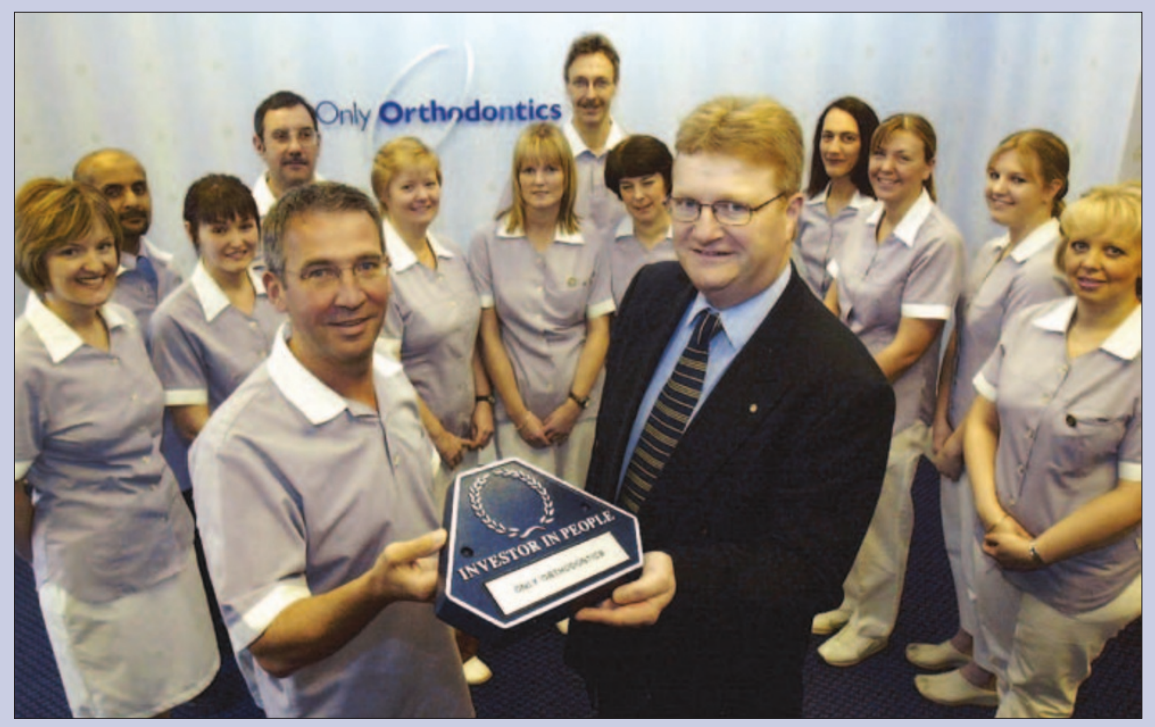

The team at Only Orthodontics celebrates achieving the Investor in People award presented by Peter Hanson (right) of Business-Link West Yorkshire. Principal Orthodontist John Derbyshire (left) established the predominately NHS practice in central Huddersfield 9 years ago.

\section{Double accolade}

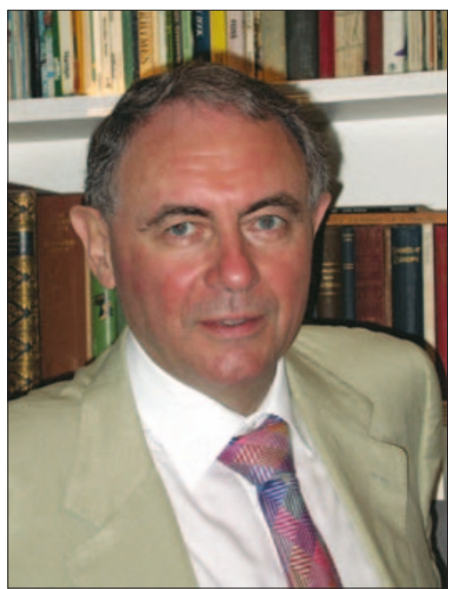

Professor Newell Johnson was recently awarded the John Tome's Medal for outstanding services to the dental profession and to the BDA at its 2004 Annual Meeting. In addition he was also elected President of the Section of Odontology of the Royal Society of Medicine for the second time.

Professor Johnson is currently Professor of Oral Health Sciences and Head of the Oral Health Research Group at the Dental Institute of King's College London, Director of the WHO Collaborating Centre for Oral Cancer and Precancer and is also President of the British Society for Dental Research. He is currently active in research in many parts of the world and holds honorary professorial appointments at universities in South Africa, Kenya and India. 